\title{
How to build science-action partnerships for local land-use planning and management: lessons from Durban, South Africa
}

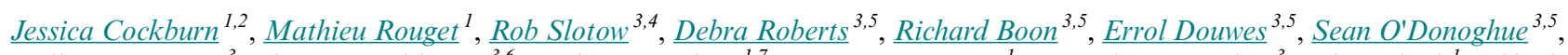 \\ Colleen T. Downs $^{3}$, Shomen Mukherjee ${ }^{3,6}$, Walter Musakwa $^{1,7}$, Onisimo Mutanga ${ }^{1}$, Tarombera Mwabvu ${ }^{3}, \underline{\text { John Odindi }}^{1}, \underline{\text { Alfred }}^{3}$

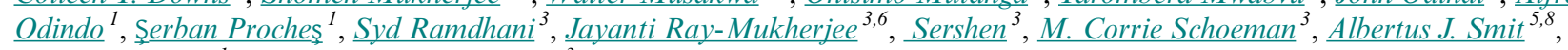 \\ Edilegnaw Wale ${ }^{1}$ and Sandi Willows-Munro
}

\begin{abstract}
The gap between scientific knowledge and implementation in the fields of biodiversity conservation, environmental management, and climate change adaptation has resulted in many calls from practitioners and academics to provide practical solutions responding effectively to the risks and opportunities of global environmental change, e.g., Future Earth. We present a framework to guide the implementation of science-action partnerships based on a real-world case study of a partnership between a local municipality and an academic institution to bridge the science-action gap in the eThekwini Municipal Area, South Africa. This partnership aims to inform the implementation of sustainable land-use planning, biodiversity conservation, environmental management, and climate change adaptation practice and contributes to the development of human capacity in these areas of expertise. Using a transdisciplinary approach, implementation-driven research is being conducted to develop several decision-making products to better inform land-use planning and management. Lessons learned through this partnership are synthesized and presented as a framework of enabling actions operating at different levels, from the individual to the interorganizational. Enabling actions include putting in place enabling organizational preconditions, assembling a functional well-structured team, and actively building interpersonal and individual collaborative capacity. Lessons learned in the case study emphasize the importance of building collaborative capacity and social capital, and paying attention to the process of transdisciplinary research to achieve more tangible science, management, and policy objectives in science-action partnerships. By documenting and reflecting on the process, this case study provides conceptual and practical guidance on bridging the science-action gap through partnerships.
\end{abstract}

Key Words: biodiversity conservation; boundary organization; climate change adaptation; collaboration; environmental management; sustainable development; transdisciplinary research.

\section{INTRODUCTION}

A disconnect between scientific knowledge and implementation of such knowledge on the ground is apparent in many fields that seek to address sustainability challenges, including biodiversity conservation, environmental management, and climate change adaptation (Moser and Dilling 2011, Cook et al. 2013, Knight 2013, O'Brien 2013, Swilling 2014, van Kerkhoff 2014). For example, despite the recognized importance of management and conservation of threatened ecosystems (Keith et al. 2013), few scientific recommendations published in mainstream conservation journals are fully implemented (Whitten et al. 2001, Knight et al. 2008), and practical conservation and environmental management actions are not always informed by best-available science (Pullin et al. 2004, McNie 2007). This phenomenon has been termed in various ways, including the "theoryimplementation gap" (Arlettaz et al. 2010), the "knowing-doing gap" (Pfeffer and Sutton 2000, Knight et al. 2008), the "knowledge-action boundary" (Cook et al. 2013), the "sciencepolicy nexus" (Gaffy 2008) or "interface" (Swilling 2014), the "science-management divide" (Roux et al. 2006), or the "scienceaction gap" (Reyers et al. 2010), which we use here. As a result of the difficulties in closing such gaps, calls have been made in the literature for scientists and practitioners to jointly address sustainability challenges such as biodiversity loss, environmental degradation, and climate change (van Kerkhoff and Lebel 2006, Knight et al. 2008, Arlettaz et al. 2010, Moser and Dilling 2011, Laurance et al. 2012, Cook et al. 2013). Although we recognize that several forms of knowledge, such as local indigenous knowledge and lay knowledge, play an important role in informing practice (Maiello et al. 2013), this study focuses on the two-way linkages between scientific knowledge generated at academic research institutions and the work of practitioners in local government whereby research can inform practice, and practice can inform research.

\section{The science-action gap}

Bridging the gap between science and action is increasingly important given the complexity of most environmental problems and the need to involve a broad range of stakeholders (Hirsch Hadorn et al. 2007a, Shackleton et al. 2009, Pooley et al. 2014, van Kerkhoff 2014). Potential reasons for the science-action gap in sustainability challenges have been well documented and include the following:

- Over-reliance on linear approaches: Most efforts to bridge the science-action gap assume a "trickle-down" or a "technology transfer" model (van Kerkhoff and Lebel

${ }^{1}$ School of Agricultural, Earth and Environmental Sciences, University of KwaZulu-Natal, ${ }^{2}$ Department of Environmental Science, Rhodes University, ${ }^{3}$ School of Life Sciences, University of KwaZulu-Natal, ${ }^{4}$ Department of Genetics, Evolution, and Environment, University College, London, ${ }^{5}$ Environmental Planning and Climate Protection Department, eThekwini Municipality, ${ }^{6}$ School of Liberal Studies, Azim Premji University, Bengaluru, India, ${ }^{7}$ Department of Town and Regional Planning, Faculty of Engineering and the Built Environment, University of Johannesburg, ${ }^{8}$ Biodiversity and Conservation Biology Department, Faculty of Natural Science, University of the Western Cape 
2006), which have a linear approach to transferring information from researchers to practitioners or decision makers. This is problematic because it does not sufficiently recognize the role of participation, integration, learning, and negotiation (Roux et al. 2006, van Kerkhoff and Lebel 2006, McNie 2007).

- Power imbalances, negotiation, and coproduction of knowledge: The boundary between science and society is an artificial one, but one that is characterized by strong power differentials and assumptions about the superiority of scientific knowledge (van Kerkhoff and Lebel 2006, van Kerkhoff 2014). Overcoming such boundaries requires negotiation and openness from both sides to see knowledge from different perspectives and be willing to coproduce knowledge (Gibbons et al. 1994, Hegger et al. 2012, Cundill et al. 2015).

- Insufficient attention to processes, including social learning: There is often too much focus on technical "knowledge management solutions" and insufficient focus on the role of people in transferring knowledge informally, or the importance of suitable processes such as social learningbased approaches (Pfeffer and Sutton 2000, Leeuwis and Pyburn 2002, Shackleton et al. 2009).

- Insufficient reflection on underlying philosophies and assumptions: There is an important difference between "what?" knowledge (technical knowledge) and "why?" knowledge (knowledge about the motivations for certain actions, based on underlying philosophies and values). Organizations that implement new technical knowledge, without reflecting on and making the necessary changes to underlying assumptions, may fail to bring about the desired changes (Pfeffer and Sutton 2000, Wals 2011, O'Brien 2013).

- Not enough recognition of the uncertainty and complex systems in which decision making and implementation of knowledge takes place, along with assumptions that the generalizable outcomes of research are applicable across diverse contexts of practice and decision making (Uhl-Bien et al. 2007, van Kerkhoff 2014).

- Mismatches between the knowledge that researchers generate and that which practitioners require in their decision making and practice (van Kerkhoff and Lebel 2006, McNie 2007).

\section{Transdisciplinary research to bridge the science-action gap}

Numerous solutions have been proposed to bridge the scienceaction gap, including, for example, integration science, which makes links to complexity thinking (van Kerkhoff and Lebel 2006, van Kerkhoff 2014), coproduction of knowledge and the need to build coproductive capacity (Wyborn 2015), joint knowledge production (Hegger et al. 2014), evidence-based conservation (Stewart et al. 2005), conservation partnerships (Stelzer and Kashian 2014), mental models (Biggs et al. 2011), learning organizations (Cowling et al. 2008, O'Farrell and Anderson 2010), boundary organizations (McNie 2007, Franks 2010), and transdisciplinary research (Max-Neef 2005, Hirsch Hadorn et al. 2007b, Lang et al. 2012). The case study presented in this paper explicitly takes a transdisciplinary research approach to bridge the science-action gap.
Transdisciplinarity offers an integrative form of knowledge generation and decision making based on research collaborations among scientists from different disciplines and stakeholders from business, government, and civil societies (Pohl 2008, Rice 2013, Sitas et al. 2014, Swilling 2014). For the purpose of this study we use the following definition of transdisciplinarity (Lang et al. 2012:26): "Transdisciplinarity is a reflexive, integrative, methoddriven scientific principle aiming at the solution or transition of societal problems and concurrently of related scientific problems by differentiating and integrating knowledge from various scientific and societal bodies of knowledge." For scientists, this means collaborating across disciplines, and with practitioners and policy makers and other stakeholders to address societal problems; for practitioners, this means working with scientists to improve implementation practices, through more effective problem solving.

Despite calls in the literature for conservation and environmental researchers to address the science-action gap, along with suggested models for how this might be done, few successful case studies have been published in the literature (but see Roux et al. 2006, Shackleton et al. 2009, Arlettaz et al. 2010). There is also as a lack of methodological development for integrated research and action (van Kerkhoff 2014). Examples of either theory or empirical insights from practice in the developing country context are also scarce, although research from South Africa on the science-action gap in conservation (Roux et al. 2006, Knight et al. 2008, Reyers et al. 2010), ecosystem services (Cowling et al. 2008, Sitas et al. 2014), and sustainability science (Swilling 2014, Cundill et al. 2015) is growing. We aim to address these gaps in the literature and contribute to the growing field of transdisciplinary research to bridge the science-action gap.

\section{THE NEED FOR SCIENCE-ACTION PARTNERSHIPS TO INFORM LOCAL LAND-USE PLANNING: THE CASE OF DURBAN}

\section{Land-use planning for environmental sustainability}

Local land-use decisions can have negative impacts on biodiversity and ecosystem services, for example through habitat loss and transformation (Seto et al. 2012). Mitigation of such impacts, however, can be achieved through incorporation of biodiversity management and climate change adaptation into local land-use planning and decision-making processes (Roberts et al. 2012). For many years, eThekwini Municipality has incorporated environmental sustainability principles into local land-use planning and decision making (Roberts and Diederichs 2002), which has raised the profile of biodiversity management and climate change adaptation in the city (see Appendix 1).

Land-use planning and decision making should be underpinned by credible scientific research, and concomitant engagement with all relevant stakeholders (Cilliers et al. 2014). This is particularly important in contexts where land is a strategic and politically contested resource, as it is in the eThekwini Municipal Area. Successful environmental planning and management requires highly skilled people, influential decision makers, a sound scientific, evidence-based knowledge foundation, and the political will to implement policies (Sitas et al. 2014). The shortage of human capacity and specialist skills in local government departments working on biodiversity and environmental matters 
has been identified not only in Durban (Roberts et al. 2012) but also elsewhere in South Africa (Wilhelm-Rechmann and Cowling 2011, Funke and Nienaber 2012, Ivey et al. 2013). Recognition of this capacity shortage, and the need to close the science-action gap in Durban, led to the development of the Durban Research Action Partnership described below (Roberts et al. 2012).

\section{Case study overview: introducing the research partnership}

Acknowledgement of the need to close the science-action gap has led to several calls, from the international to the local level, to develop innovative solutions to address the challenges and opportunities of global environmental research (e.g., Future Earth, http://www.futureearth.org/). In Durban, South Africa, this resulted in the development of a research partnership initiated by eThekwini Municipality's (EM) Environmental Planning and Climate Protection Department with a local tertiary institution, the University of KwaZulu-Natal(UKZN), known as the Durban Research Action Partnership (D'RAP; Roberts et al. 2012). EThekwini Municipality (referred to hereafter as the Municipality) is the local government authority in the city of Durban. Durban is located within a global biodiversity hotspot, the Maputaland-Pondoland-Albany Hotspot (Steenkamp et al. 2004), and contains a number of endangered ecosystems, including the KwaZulu-Natal Sandstone Sourveld (KZNSS) grassland (Mucina and Rutherford 2006), which is the current focus of the research partnership, through the implementation of the KZNSS Research Program (Appendix 1).

Setting up partnerships takes time and resources, and this critical lead-in stage is often overlooked (Pooley et al. 2014). Although D'RAP was formally founded in 2011, the history of its development goes back to the early 2000s, at which time EM and UKZN staff engaged in various joint activities to build capacity within the Municipality and to up-skill university graduates for positions therein. These various engagements over a period of eight years laid the foundations for the success of the partnership in the long-term through open, honest working relationships and trust-building (Harris and Lyon 2013). A detailed account of the history of the partnership is presented in Appendix 2. The methods and empirical data sources used in development of the case study are described in Appendix 3.

The Durban Research Action Partnership explicitly addresses the science-action gap, while at the same time addressing a critical local skills shortage within the fields of biodiversity management and climate change adaptation. It seeks to better manage a threatened ecosystem through researching the impacts of global change (with a particular focus on climate change) on biodiversity and ecosystems, within an urban landscape in a developing country. The research is conducted primarily by postgraduate students, who are supervised by principal investigators across a variety of disciplines, including ecology, molecular biology, agricultural economics, geography, environmental science, and conservation planning and management. Research projects are jointly developed by the partners, but are driven by the management and decision-making knowledge needs of eThekwini Municipality. The research partnership is core-funded by eThekwini Municipality, with researchers leveraging additional funds from the university and other sources. The secretariat of the partnership is based in the Land Use Planning and Management research group at the university, which provides administrative, financial, and advisory support for the partnership. The partnership has a strong focus on communication across the science-action divide, capacity building, and emphasizes a social learning approach in which continuous evaluation and reflection play an important role.

\section{LESSONS FROM IMPLEMENTING A SCIENCE-ACTION PARTNERSHIP}

Through its 11-year journey, D'RAP has built a strong foundation for long-term collaboration. The lessons learned through this process have been synthesized into a framework of recommendations for successful implementation of scienceaction partnerships (Fig. 1). The framework consists of four broad enabling actions, each one based on a number of specific factors. The four broad enabling actions are as follows: (a) explicitly address the science-action gap, (b) put in place enabling organizational preconditions, (c) assemble a functional wellstructured team, and (d) actively build interpersonal and individual collaborative capacity. The enabling actions operate at a number of different levels, which are nested in one another from the level of the individual, to the team and intra- and interorganizational levels. For each enabling action, we highlight in detail some of the key factors to provide practical insights from our experiences which may be useful to others involved in similar initiatives.

Fig. 1. Enabling actions for building successful partnerships to bridge the science-action gap. These occur at a number of levels: (a) interorganizational: explicitly address the scienceaction gap, (b) intra-organizational: put in place enabling organizational preconditions, (c) team: assemble a functional, well-structured team, and (d) team and individual: actively build collaborative capacity (interpersonal and individual). See Box 1-3 for further details and examples from the case study.

Action a: Explicitly address the science-action gap

- Build a boundary organization

- Develop a shared conceptual research framework

- Conduct research with implementation in mind

- Allow balanced space for science and practice to contribute

Action b: Put in place enabling organizational preconditions

- Transparency \& accountability • Incentives

- Broad, inclusive participation - Clear expectations

- Sharing resources - Social capital development

- Institutional support

- Formal, binding agreement

- Continuous evaluation and

- Good communication

Action c: Assemble a functional, well-structured team

- Enabling leaders - Process champions

- Institutional champions . Helpful critics

- Brokers

- Content champions

- Administrative support staff

Action d: Actively build collaborative capacity at interpersonal and individual levels INTERPERSONAL INDIVIDUAL - Build new relationships. Flexibility and adaptability - Build new relationships - Flexibility and adaptability - Manage confil - Openness - Openness - Experience 


\section{Action a: Explicitly address the science-action gap}

Recognizing the challenges of working at the science-action interface is crucial to the success of such partnerships (Knight et al. 2008, Lang et al. 2012). This is the first enabling action of the framework presented here (Fig. 1a). It operates at the interorganizational level and provides an overarching enabling environment for the other three enabling actions, operating at lower levels. This action should therefore be put in place quite early in the partnership. To achieve this, D'RAP established an overarching vision that operationalized a transdisciplinary research model and we discuss here two key contributing factors: building a boundary organization and developing a joint conceptual research framework.

\section{Building a boundary organization}

The Durban Research Action Partnership can be interpreted as a boundary organization, which explicitly recognizes the boundary between science and society, and acknowledges the cultural and institutional barriers to the implementation of scientific research (McNie 2007, Cook et al. 2013). The transdisciplinary research process, in which such boundary organizations engage, can be divided into a number of stages. (Lang et al. 2012; Fig. 2). The research partnership developed in line with these stages as follows:

Fig. 2. Conceptual model of the transdisciplinary research process put into practice through the KwaZulu-Natal Sandstone Sourveld Research Program and the broader Durban Research Action Partnership (Adapted from Lang et al. 2012).

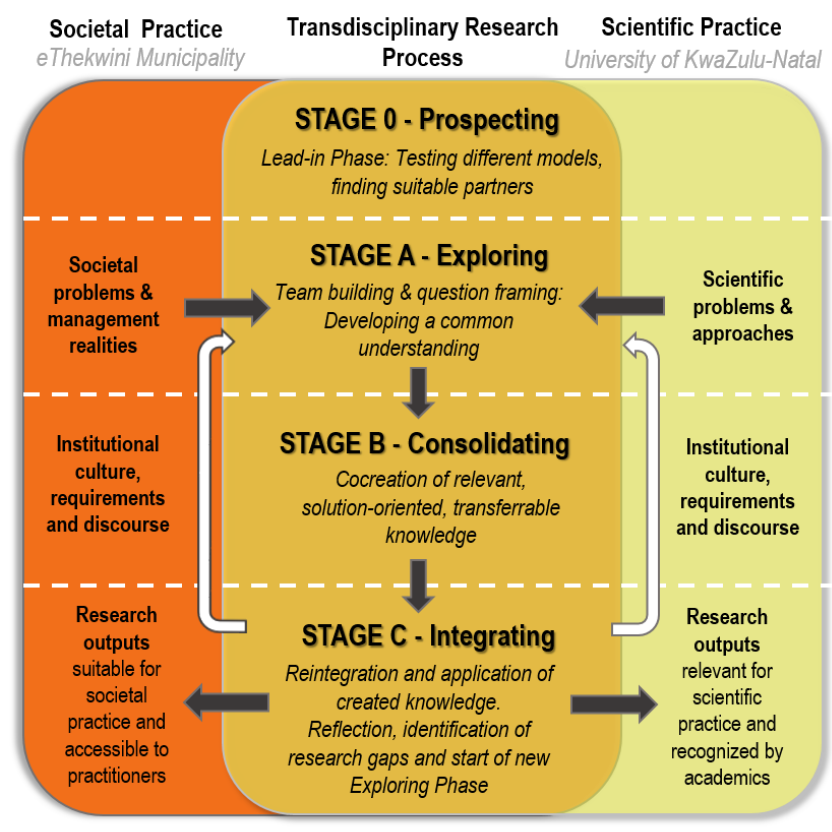

- Stage 0 - Prospecting: In this stage, enabling leadership (UhlBien et al. 2007, Galuska 2014), interpersonal relationships, and trust-building (Harris and Lyon 2013) in the development of the team play an important role in laying the foundations for future collaboration. The history of
D'RAP, as described in Appendix 2, incorporated a long lead-in stage of engagements, illustrated as "Stage 0: Prospecting." This entailed a series of experiments to test various approaches to building capacity and generating knowledge, to develop a mutually beneficial collaborative partnership and build trust. This stage was not included in the original model for transdisciplinary research proposed by Lang et al. (2012), and is often overlooked in setting up partnerships, thus we propose it for particular consideration by others implementing similar partnerships.

- Stage A - Exploring: The importance of a "scoping" or exploratory stage such as this is highlighted by Pooley et al. (2014), and requires significant time investments and regular face-to-face interactions (Stokols et al. 2003). In this stage of the partnership, the emphasis was on building a collaborative research team for the KZNSS Research Program, coming to agreement on a joint vision, and broad framing of research questions. The initial research questions and objectives of the partnership were kept broad to encourage researchers from as many different disciplines as possible to join the program early on, i.e., to "cast the net wide."

- Stage B - Consolidating: During this stage, the identity, goals, objectives, research questions, and mechanisms of the partnership were formalized and refined, and team assembly was consolidated through the appointment of secondary leaders, one from each institution. Because the primary leaders who initiated the engagement could not afford the intensive time investments required to lead the KZNSS Research Program, the two secondary leaders, and various support staff appointed to assist them, took over the leadership roles. Importantly, the two primary leaders remained directly involved in the oversight and strategic direction of the partnership. A strong steering committee, including both levels of leadership, closely managed budgets and implementation. To further consolidate the partnership, a conceptual research framework was jointly developed and research was initiated to begin generating knowledge (See Appendix 4).

- Stage C - Integrating: In D'RAP, Stage C has only recently been initiated, and limited success has been achieved. The goal during this stage is to ensure that research outputs are integrated successfully into decision making and management, and that these are based on jointly formulated research questions. The main tool used for this is the development of a "decision-making products" framework (Appendix 4, Fig. A4.1). This stage also includes an evaluation of the research process.

Building the boundary organization, through the development of a collaborative, transdisciplinary research team in D'RAP, required a high level of commitment from the leaders and initiators of the partnership. This is typical of such partnerships, where many barriers need to be overcome (Rice 2013). These barriers, which are widely reviewed in the literature, include the following: difficulty in overcoming disciplinary and institutional boundaries, differences in work cultures across institutions, different language and frames of reference, limited funding opportunities, institutional rewards and incentives that do not 
encourage transdisciplinary research, high time and resource investments required, deficiency in skills required to manage integrative research processes, and the high level of communication and facilitation required for success (Pohl 2008, Rice 2013, Goring et al. 2014, Pooley et al. 2014).

Developing boundary organizations that focus on social learning processes to bridge the science-action divide requires sustained long-term interactions between role-players, and it is often the improved knowledge-sharing capacity of the respective institutions that have greater impacts on the ground than the actual research outputs (Shackleton et al. 2009). The research partnership experienced many of the barriers described above. For example, early on in the partnership, Dr. Debra Roberts (cofounder of the partnership) described meetings between academics from the university and practitioners from eThekwini Municipality as "tense" (D. Roberts, personal communication, 2014). There were different expectations from the two parties. There were financial, administrative, and program coordination problems because of a shortage of staff, which also generated frustration among participants. Since inception of the research partnership in 2011, some attrition has occurred, with some participants, who did, however, provide helpful criticism, leaving the partnership. It appears that the younger, emerging researchers were inclined to be more flexible as was required for the transdisciplinary research approach. This highlights some of the difficulties that might be encountered when building such a boundary organization. It is not simply about the codesign of research programs and the cogeneration of knowledge, but also about building social capital through the development of new working relationships and networks (Gray 2008, Harris and Lyon 2013), good communication skills (Stokols et al. 2003), building trust (McNie 2007, Cheruvelil et al. 2014), and developing the collaborative capacity of participants (Hall et al. 2008; Boxes 2 and 3). Critical to all of these is enabling leadership, which fosters an environment of innovation, adaptation, and learning (Galuska 2014).

\section{Joint development of a conceptual research framework}

The process of developing a shared conceptual research framework can become a tangible expression of the joint research vision of a collaborative partnership (Morse et al. 2007). To successfully bridge the science-action gap, research should be designed with implementation in mind (Knight et al. 2008). More importantly, the researchers and implementers have to work together in a balanced way on the design of the research agenda, plan of action, and implementation strategies (Gray 2008). This constitutes a key lesson learned through this and other similar partnerships (Morse et al. 2007, Arlettaz et al. 2010; Fig. 1a). As D'RAP progressed (into Stage B, Fig. 2), a more focused conceptual research framework was developed. This ensured that proposed research projects were better aligned with the Municipality's research needs for biodiversity management and climate change adaptation (Appendix 4).

\section{Action b: Put in place enabling organizational preconditions}

The second enabling action involves a range of organizational preconditions required to operationalize a transdisciplinary research approach (Hall et al. 2008; Fig. 1b and Box 1). We found that enabling leadership (Galuska 2014) was critical for setting the tone and developing shared mental models for the partnership.
Other factors include transparency, inclusive participation, sharing of resources, and good communication (Gray 2008). We focus the discussion on continuous evaluation and reflection, one of the enabling organizational preconditions that has been given particular prominence in D'RAP.

Box 1: Enabling organizational preconditions required for successful science-action partnerships and how these were implemented in the Durban Research Action Partnership (indicated as bullet points below each enabling factor):

Transparency and accountability (Harris and Lyon 2013)

- Planning and decision-making meetings open to participants from both institutions

- Memorandum of Agreement (MOA) available to everyone

- Oversight and accountability through reporting to parent organizations as stipulated in the MOA

Broad and inclusive participation with influence over decisions (Galuska 2014)

- Cast the net wide: Participation in the partnership open to all university researchers, across disciplines

- Team members from both the university and Municipality given opportunity to shape the partnership

Sharing resources rather than monopolizing

- Research project funding evenly shared between researchers, i.e., senior researchers did not receive disproportionately larger amounts

Institutional support: In-principle support of the partnership as well as project support, e.g., administrative and financial (Goring et al. 2014)

- High-level institutional support secured by both partners early on

- Insufficient administrative and financial support at the start. In response, resources were mobilized and support staff were appointed specifically for the partnership.

Formal, binding contractual agreement between institutions (Harris and Lyon 2013)

- MOA signed between university and Municipality, which laid out the rules of engagement

Suitable incentives for partners with different objectives (Harris and Lyon 2013)

- Formal incentives have not yet been fully developed

- For researchers: publish more joint papers, university to recognize their participation in collaborative research

- For practitioners: better alignment of research projects with practitioners' responsibilities

Good communication: internal and external (Galuska 2014)

- Numerous and varied opportunities for face-to-face communication, e.g., regular meetings, working groups, field trips. 
- External communication about the program through presentations and articles in local publications such as magazines and newsletters.

Clarify expectations (Goring et al. 2014)

- The KZNSS Research Program experienced some tensions around expectations in the early stages: taking time to clarify expectations from both parties may have reduced such tensions.

Actively building social capital (Cheruvelil et al. 2014)

- Leaders propose collaborations among specific researchers for integration across disciplines

- Social capital could be improved by spending more time on social engagements outside of the formal work environment to improve interpersonal engagement

Continuous evaluation and reflection (Stokols et al. 2003, Roux et al. 2010)

- Formal evaluation (of both outcomes and process) is ongoing and specific time is allocated for these activities

- Evaluation activities are participatory and include opportunities for reflection at individual and team level.

\section{Continuous evaluation and reflection}

Collaborative, transdisciplinary research partnerships require continuous, reflective evaluation (Stokols et al. 2003, Roux et al. 2010). Assessing the process of research within such a partnership is critical because the process itself needs to be effective if useful information is to be generated (McNie 2007), and it is only through reflective evaluation that team members themselves can learn about the transdisciplinary process (Roux et al. 2010). Thus, a process evaluation was initiated in D'RAP (Ferreyra and Beard 2007) to understand participants' perceptions of the following: science outcomes; collaborative management outcomes, as measured through the following indicators: each individual's personal increase in scientific understanding, capacity building, and alliance building; and the administrative and financial arrangements of the program.

The process evaluation was conducted in two phases: First, an electronic, anonymous questionnaire was circulated to all participants of the program, and second a workshop was held during which the results were "mirrored back" to the participants (Engeström, 1987) and they were asked to reflect on the results and on their participation in the program as a whole (Ferreyra and Beard 2007). For the reflection process, participants were asked to record two items on a card: (1) what they would like to change about the partnership, and (2) what they would not like to change about the partnership. As part of the evaluation questionnaire, participants were asked to suggest solutions to the challenges that were faced in the program. The following themes for improvement were identified:

- Reduce administrative load, i.e., get additional human resources support,
- Better planning of meetings and timing to coincide with low periods of activity in the academic calendar,

- Improved financial mechanisms and management,

- Better joint goal setting and understanding each other's perspectives, and

- Recruiting more high quality students.

Participants felt the program as a whole generated more knowledge about biodiversity and ecosystems than the other knowledge objectives, e.g., climate change. They also expressed that the less tangible social capital and networking outcomes, i.e., the building of collaborative capacity, were at that time more successful than the more tangible science and policy outcomes (Fig. 3). Constraints experienced by participants were mostly logistical in nature, including time constraints and a shortage of financial and administrative support. These constraints have been identified elsewhere as typical problems in collaborative, transdisciplinary research partnerships (McNie 2007, Goring et al. 2014). Other challenges identified included clashes between the different organizational cultures (Rice 2013) and finding suitable program participants (Pooley et al. 2014). These concerns will be addressed in the planning for Phase 2 of the KZNSS Research Program.

Fig. 3. Results of the evaluation: collaborative management outcomes of the research partnership as perceived by participants along a gradient from most tangible to least tangible outcomes. Key: $[\checkmark]$ : most participants agree that the partnership has achieved this outcome, [?]: some participants feel that the partnership has achieved this outcome, $[\times]$ : very few participants feel that the partnership has achieved this outcome.

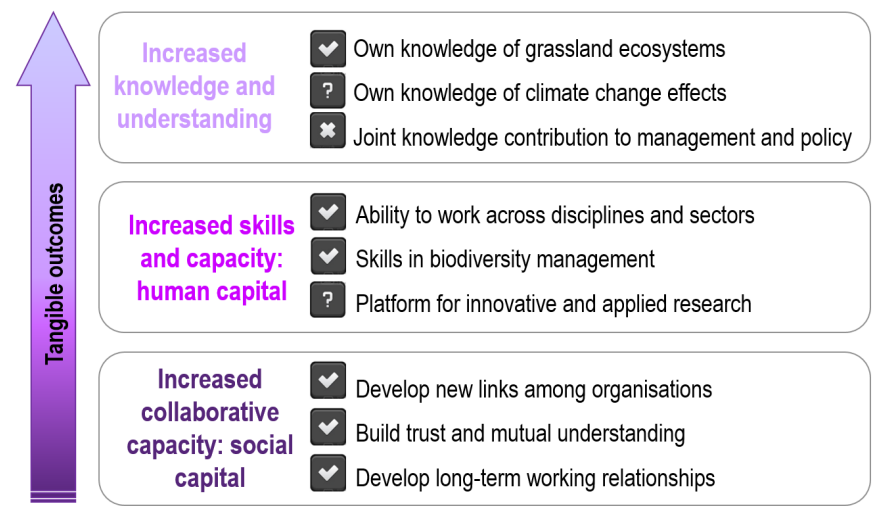

In parallel to this process evaluation, an outcome evaluation of research projects was also conducted, which took the form of a comparative gap analysis. The overall program objectives and the Municipality's research questions were compared to the results and outcomes from each of the research projects. The outcome evaluation showed the following key weaknesses of the research: (1) social and governance research aspects are not adequately addressed, (2) insufficient research focus on climate change within individual projects, and (3) local communities are not directly involved. Further details of this evaluation were published in internal project reports (see Appendix 3). 
These issues are critical because the research framework illustrates the linkages between human impacts and reliance on ecosystems (Appendix 4). It is clear that these links should be better understood through social research. The Municipality does engage with communities around issues of biodiversity management (Roberts et al. 2012, eThekwini Municipality 2013). However, such engagements are currently not an explicit part of the research partnership. Without direct engagement with communities the partnership risks alienating itself from both the communities that rely on the benefits of biodiversity in the city of Durban, and those communities that may be having negative impacts on biodiversity (Graham and Ernstson 2012). The coordination team is constantly seeking ways to respond to issues raised during the evaluation activities to ensure on-going, active participation and well-being of participants and relevance of the research not only to practitioners and policy makers at the Municipality, but also to local communities living in the eThekwini Municipal Area.

\section{Action c: Assemble a functional, well-structured team}

The third enabling action emphasizes the importance of assembling a functional, well-structured team. Although enabling organizational preconditions can be put in place by leaders (Gray 2008, Galuska 2014), these will only lead to success if teams and participants have certain characteristics to take advantage of the conducive environment (Cheruvelil et al. 2014). Therefore, team composition and interpersonal and intrapersonal or individual factors, i.e., collaborative capacity (Hall et al. 2008), play a critical role in the success of a science-action partnership (Morse et al. 2007). Assembling a functional, well-structured team means that coordination teams need to recruit participants who can fulfil certain roles or functions within the team, which include among others enabling leaders, institutional champions, and brokers (Hall et al. 2008, Wale et al. 2009, Long et al. 2013; Box 2; Fig. 1c). Identifying suitable participants to fulfil these roles formed part of the "Consolidating" phase of D'RAP.

Box 2: Key factors required in the team assembly of science-action partnerships and how these were implemented in the Durban Research Action Partnership:

Enabling leaders (Uhl-Bien et al. 2007, Galuska 2014)

- Enabling leadership was demonstrated by the primary leaders ${ }^{[1]}$ from both the Municipality and the university.

- A secondary level of leadership was introduced into the partnership, which maintained an enabling model of leadership.

Institutional champions (Wale et al. 2009)

- Both primary leaders, from the Municipality and the university, are well respected and hold high positions in their institutions.

Brokers or boundary spanners (Long et al. 2013)

- Secondary leaders from the university and the Municipality, along with their support staff, acted as brokers.

- The role of brokers is multifaceted: they can act as "buffers" or as "glue" to bridge the gap between institutional cultures. Both these roles were fulfilled by secondary leaders and support staff.

\section{Content champions (Gray 2008)}

- Among the secondary leaders, those with technical and scientific competencies directly relevant to the research goals of the partnership played an important role.

Process champions (Gray 2008, Wale et al. 2009)

- Among the secondary leaders and support staff, some showed particular competencies in leading the process and actively contributing to building bridges, facilitating learning and ensuring on-going evaluation and reflection.

\section{Helpful critics}

- Some research participants did not remain involved in the research partnership because they were dissatisfied with the process.

- Their criticisms were useful feedback for the process leaders and forced reflection on some of the challenges that participants face in crossing traditional boundaries.

Administrative support staff (Goring et al. 2014)

- When the research partnership was launched there was a shortage of administrative support staff that hampered progress and frustrated participants.

- Since the appointment of such people in the partnership, participants are less burdened by project administration.

${ }^{[1]}$ Note: The primary leaders were the two leaders who initiated the overall the Durban Research Action Partnership (Appendix 2). A secondary leader from each of the institutions was then appointed to implement and manage the KZNSS Research Program. The primary leaders then took a more supportive role.

Action d: Actively build collaborative capacity at interpersonal and individual levels

Last, collaborative capacity, the individual participant's or team's ability to effectively collaborate (Hall et al. 2008, Stokols et al. 2008), is the fourth enabling action to build successful partnership (Fig. 1d). The critical interpersonal processes and individual characteristics required for science-action partnerships are shown in Box 3.

Constructive interpersonal processes must be actively promoted if science-action partnerships are to succeed (Harris and Lyon 2013, Long et al. 2013). The ability of leaders or coordination teams to promote such constructive processes, such as building relationships, building trust, and managing conflict will of course depend on both the team assembly as well as the individual characteristics of participants. Examples of how such constructive interpersonal processes were promoted in D'RAP are shown in Box 3.

Transdisciplinary research, as implemented in science-action partnerships, may not be suited to all kinds of people, and it can be difficult to find the right people (Cheruvelil et al. 2014). The collaborative capacity of individuals, i.e., their personal characteristics and ability to effectively collaborate in a transdisciplinary team, can make a significant impact at multiple levels of the science-action partnership, from interpersonal 
relationships to the functioning of the team and the efficacy of the boundary organization itself (Morse et al. 2007). Specific personal characteristics that are valuable in science-action research teams, and how these were evident in D'RAP, are shown in Box 3, and include, for example, flexibility and adaptability, patience, openness, and past experience of similar partnerships.

Box 3: Building collaborative capacity: critical interpersonal processes and individual characteristics required for science-action partnerships and how these were implemented in the Durban Research Action Partnership:

Part 1: Promoting constructive interpersonal processes Building new relationships (Harris and Lyon 2013)

- Leaders had a long-established working relationship that helped their respective teams to trust each other (Appendix2).

- Open and frank discussions and negotiations in planning the partnership provided the basis for a good working relationship

Building trust (Harris and Lyon 2013)

- Trust was built on demonstrated delivery over time, especially during the lead-in phase of the partnership (Appendix 2).

- Suitable secondary leaders, acting as brokers, were recruited, and continued building relationships and trust through implementation of the KZNSS program

Managing conflict (Long et al. 2013)

- Secondary leaders and support staff played an important role in managing conflict between individuals.

- Individuals have to be more conscious of the need for conflict management when crossing disciplinary and institutional boundaries.

Part 2: Seeking out and developing individuals with critical individual characteristics

Flexibility and adaptability (Morse et al. 2007)

- Participants showed willingness to shape own research and practice expectations and activities to meet joint visions and outcomes.

- Flexibility was particularly evident among younger, emergent researchers

Patience (Morse et al. 2007)

- Some team members were frustrated by the slow pace at which the partnership developed and generated knowledge; they left early.

- Those who demonstrated patience and were able to "see the bigger picture" have remained and are reaping the benefits.

Commitment to the collaborative process (Morse et al. 2007)

- Despite some difficulties in the early stages of setting up the partnership, the majority of participants persevered and prioritized the partnership in their work, met deadlines, and contributed time and intellectual input.
Openness: ability to innovate, experiment, and learn (Harris and Lyon 2013, Galuska 2014)

- Emergent researchers were more open to new ideas than established researchers may have been.

- Most participants demonstrated a willingness to learn about "the other side," i.e., research or practice, and about other disciplines.

- Participants were prepared to jointly develop a conceptual framework, even if it took a different approach to their discipline.

Experience of similar collaborations (Harris and Lyon 2013)

- Those leaders and participants who had previous experiences of either a similar collaborative program, or had worked with each other before, appeared to more easily adjust to the demands of the transdisciplinary process and build relationships.

\section{CONCLUSION}

To contribute to solving societal problems, institutions must recognize the importance of explicitly bridging the science-action gap to address complex, interlinked social-ecological problems (Max-Neef 2005, Shackleton et al. 2009). This requires bridging traditional disciplinary and institutional boundaries through a transdisciplinary process (Lang et al. 2012) and investing in building collaborative capacity (Hall et al. 2008, Cheruvelil et al. 2014). By documenting and reflecting on such a process, this case study has provided conceptual and practical guidance on bridging the science-action gap through partnerships. This includes the following:

- Empirical insights on how to operationalize a transdisciplinary research process;

- Recommendations for specific actions at a number of different levels in science-action partnerships (see framework presented in Fig. 1);

- Recognition of the need for a lengthy prospecting stage that may be required before embarking on a transdisciplinary process;

- The importance of continuous evaluation of outcomes and processes.

Through continuous evaluation and reflection of successes and failures, we have established that this partnership is on a successful trajectory based on the following aspects: (1) strong working relationships growing over time; (2) trust and social capital developed; (3) human capacity built; and (4) implementationdriven knowledge generated. The success of this partnership lies not necessarily in completely bridging the gap and reaching all the research and implementation objectives, because this is a work in progress, but in building the partnership and thereby creating suitable conditions and mechanisms needed to bridge the gap. We encourage similar partnership initiatives to use and evaluate our framework, and to document individual case studies to fast-track 
the learning on how to establish effective transdisciplinary boundary organizations in a wide range of contexts.

Responses to this article can be read online at: http://www.ecologyandsociety.org/issues/responses. php/8109

\section{Acknowledgments:}

The authors would like to acknowledge funding from eThekwini Municipality and from the South African Research Chairs Initiative of the Department of Science and Technology and National Research Foundation of South Africa. Thank you to Dr. B. Egoh and Dr. G. Cundill for reviewing earlier versions of the manuscript. The students and other participants in the KwaZulu-Natal Sandstone Sourveld Research Programme are thanked for their participation in this science-action partnership, particularly for the feedback they provided in the process evaluation questionnaire. We are grateful to two anonymous reviewers who provided valuable comments and suggestions that assisted us greatly in improving the paper.

\section{LITERATURE CITED}

Arlettaz, R., M. Schaub, J. Fournier, T. S. Reichlin, A. Sierro, J. E. M. Watson, and V. Braunisch. 2010. From publications to public actions: when conservation biologists bridge the gap between research and implementation. BioScience 60 (10):835-842. http://dx.doi.org/10.1525/bio.2010.60.10.10

Biggs, D., N. Abel, A. T. Knight, A. Leitch, A. Langston, and N. C. Ban. 2011. The implementation crisis in conservation planning: could "mental models" help? Conservation Letters 4(3):169-183. http://dx.doi.org/10.1111/j.1755-263X.2011.00170.x

Cheruvelil, K. S., P. A. Soranno, K. C. Weathers, P. C. Hanson, S. J. Goring, C. T. Filstrup, and E. K. Read. 2014. Creating and maintaining high-performing collaborative research teams: the importance of diversity and interpersonal skills. Frontiers in Ecology and the Environment 12(1):31-38. http://dx.doi. org/10.1890/130001

Cilliers, S., M. du Toit, J. Cilliers, E. Drewes, and F. Retief. 2014. Sustainable urban landscapes: South African perspectives on transdisciplinary possibilities. Landscape and Urban Planning 125:260-270. http://dx.doi.org/10.1016/j.landurbplan.2014.02.009

Cook, C. N., M. B. Mascia, M. W. Schwartz, H. P. Possingham, and R. A. Fuller. 2013. Achieving conservation science that bridges the knowledge-action boundary. Conservation Biology 27 (4):669-678. http://dx.doi.org/10.1111/cobi.12050

Cowling, R. M., B. Egoh, A. T. Knight, P. J. O'Farrell, B. Reyers, M. Rouget, D. J. Roux, A. Welz, and A. Wilhelm-Rechman. 2008. An operational model for mainstreaming ecosystem services for implementation. Proceedings of the National Academy of Sciences 105(28):9483-9488. http://dx.doi.org/10.1073/pnas.0706559105

Cundill, G., D. J. Roux, and J. N. Parker. 2015. Nurturing communities of practice for transdisciplinary research. Ecology and Society 20(2):22. http://dx.doi.org/10.5751/es-07580-200222
Engeström, Y. 1987. Learning by expanding: an activity theoretical approach to developmental research. Orienta-Konsultit Oy, Helsinki, Finland.

eThekwini Municipality. 2013. EPCPD Strategy 2013-18: background report. Environmental Planning and Climate Protection Department, eThekwini Municipality, Durban, South Africa.

Ferreyra, C., and P. Beard. 2007. Participatory evaluation of collaborative and integrated water management: insights from the field. Journal of Environmental Planning and Management 50 (2):271-296. http://dx.doi.org/10.1080/09640560601156532

Franks, J. 2010. Boundary organizations for sustainable land management: the example of Dutch environmental co-operatives. Ecological Economics 70(2):283-295. http://dx.doi.org/10.1016/j. ecolecon.2010.08.011

Funke, N., and S. Nienaber. 2012. Promoting uptake and use of conservation science in South Africa by government. Water $S A$ 38:105-114. http://dx.doi.org/10.4314/wsa.v38i1.13

Gaffy, E. A. 2008. Meeting the challenges of policy-relevant science: bridging theory and practice. Public Administration Review 68(6):1087-1100. http://dx.doi.org/10.1111/j.1540-6210.2008.00957. $\underline{\mathrm{x}}$

Galuska, L. 2014. Enabling leadership: unleashing creativity, adaptation, and learning in an organization. Nurse Leader 12 (2):34-38. http://dx.doi.org/10.1016/j.mnl.2014.01.011

Gibbons, M., C. Limoges, H. Nowtony, S. Schwartzman, P. Scott, and M. Trow. 1994. The new production of knowledge: the dynamics of science and research in contemporary societies. Sage, London, UK.

Goring, S. J., K. C. Weathers, W. K. Dodds, P. A. Soranno, L. C. Sweet, K. S. Cheruvelil, J. S. Kominoski, J. Rüegg, A. M. Thorn, and R. M. Utz. 2014. Improving the culture of interdisciplinary collaboration in ecology by expanding measures of success. Frontiers in Ecology and the Environment 12(1):39-47. http://dx. doi.org/10.1890/120370

Graham, M., and H. Ernstson. 2012. Comanagement at the fringes: examining stakeholder perspectives at Macassar Dunes, Cape Town, South Africa-at the intersection of high biodiversity, urban poverty, and inequality. Ecology and Society 17(3):34. http://dx.doi.org/10.5751/es-04887-170334

Gray, B. 2008. Enhancing transdisciplinary research through collaborative leadership. American Journal of Preventive Medicine 35(2 Supplement):S124-S132. http://dx.doi.org/10.1016/j. amepre.2008.03.037

Hall, K. L., D. Stokols, R. P. Moser, B. K. Taylor, M. D. Thornquist, L. C. Nebeling, C. C. Ehret, M. J. Barnett, A. McTiernan, N. A. Berger, M. I. Goran, and R. W. Jeffery. 2008. The collaboration readiness of transdisciplinary research teams and centers: findings from the National Cancer Institute's TREC year-one evaluation study. American Journal of Preventive Medicine 35(2 Supplement):S161-S172. http://dx.doi.org/10.1016/ j.amepre.2008.03.035

Harris, F., and F. Lyon. 2013. Transdisciplinary environmental research: building trust across professional cultures. Environmental 
Science and Policy 31:109-119. http://dx.doi.org/10.1016/j. envsci.2013.02.006

Hegger, D., M. Lamers, A. Van Zeijl-Rozema, and C. Dieperink. 2012. Conceptualising joint knowledge production in regional climate change adaptation projects: success conditions and levers for action. Environmental Science and Policy 18:52-65. http://dx. doi.org/10.1016/j.envsci.2012.01.002

Hegger, D., A. Van Zeijl-Rozema, and C. Dieperink. 2014. Toward design principles for joint knowledge production projects: lessons from the deepest polder of the Netherlands. Regional Environmental Change 14(3):1049-1062. http://dx.doi.org/10.1007/ $\underline{\text { s10113-012-0382-6 }}$

Hirsch Hadorn, G. H., H. Hoffmann-Riem, S. Biber-Klemm, W. Grossenbacher-Mansuy, D. Joye, C. Pohl, U. Wiesmann, and E. Zemp. 2007b. The emergence of transdisciplinarity as a form of research. Pages 19-39 in G. H. Hirsch Hadorn, H. HoffmannRiem, S. Biber-Klemm, W. Grossenbacher-Mansuy, D. Joye, C. Pohl, U. Wiesmann, E. Zemp, editors. Handbook of transdisciplinary research. Springer, Dordrecht, The Netherlands.

Hirsch Hadorn, G. H., H. Hoffmann-Riem, S. Biber-Klemm, W. Grossenbacher-Mansuy, D. Joye, C. Pohl, U. Wiesmann, and E. Zemp. 2007a. Handbook of transdisciplinary research. Springer, Dordrecht, The Netherlands.

Ivey, P., H. Geber, and I. Nänni. 2013. An innovative South African approach to mentoring novice professionals in biodiversity management. International Journal of Evidence Based Coaching and Mentoring 11(1):85-111.

Keith, D. A., J. P. Rodríguez, K. M. Rodríguez-Clark, E. Nicholson, K. Aapala, A. Alonso, M. Asmussen, S. Bachman, A. Basset, E. G. Barrow, J. S. Benson, M. J. Bishop, R. Bonifacio, T. M. Brooks, M. A. Burgman, P. Comer, F. A. Comín, F. Essl, D. Faber-Langendoen, P. G. Fairweather, R. J. Holdaway, M. Jennings, R. T. Kingsford, R. E. Lester, R. M. Nally, M. A. McCarthy, J. Moat, M. A. Oliveira-Miranda, P. Pisanu, B. Poulin, T. J. Regan, U. Riecken, M. D. Spalding, and S. ZambranoMartínez. 2013. Scientific foundations for an IUCN Red List of Ecosystems. PLoS ONE 8(5):e62111. http://dx.doi.org/10.1371/ journal.pone.0062111

Knight, A. T. 2013. Reframing the theory of hope in conservation science. Conservation Letters 6(6):389-390. http://dx.doi. org $/ 10.1111 /$ conl.12078

Knight, A. T., R. M. Cowling, M. Rouget, A. Balmford, A. T. Lombard, and B. M. Campbell. 2008. Knowing but not doing: selecting priority conservation areas and the researchimplementation gap. Conservation Biology 22(3):610-617. http:// dx.doi.org/10.1111/j.1523-1739.2008.00914.x

Lang, D. J., A. Wiek, M. Bergmann, M. Stauffacher, P. Martens, P. Moll, M. Swilling, and C. J. Thomas. 2012. Transdisciplinary research in sustainability science: practice, principles, and challenges. Sustainability Science 7(1):25-43. http://dx.doi. org/10.1007/s11625-011-0149-X

Laurance, W. F., H. Koster, M. Grooten, A. B. Anderson, P. A. Zuidema, S. Zwick, R. J. Zagt, A. J. Lynam, M. Linkie, and N. P. R. Anten. 2012. Making conservation research more relevant for conservation practitioners. Biological Conservation 153:164-168. http://dx.doi.org/10.1016/j.biocon.2012.05.012
Leeuwis, C., and R. Pyburn. 2002. Wheelbarrows full of frogs: social learning in rural resource management: international research and reflections. Koninklijke Van Gorcum, Assen, The Netherlands.

Long, J. C., F. C. Cunningham, and J. Braithwaite. 2013. Bridges, brokers and boundary spanners in collaborative networks: a systematic review. BMC Health Services Research 13(1):1-13. http://dx.doi.org/10.1186/1472-6963-13-158

Maiello, A., C. V. Viegas, M. Frey, and J. L. D. Ribeiro. 2013. Public managers as catalysts of knowledge co-production? Investigating knowledge dynamics in local environmental policy. Environmental Science and Policy 27:141-150. http://dx.doi. org/10.1016/j.envsci.2012.12.007

Max-Neef, M. A. 2005. Foundations of transdisciplinarity. Ecological Economics 53(1):5-16. http://dx.doi.org/10.1016/j. ecolecon.2005.01.014

McNie, E. C. 2007. Reconciling the supply of scientific information with user demands: an analysis of the problem and review of the literature. Environmental Science and Policy 10 (1):17-38. http://dx.doi.org/10.1016/j.envsci.2006.10.004

Morse, W. C., M. Nielsen-Pincus, J. E. Force, and J. D. Wulfhorst. 2007. Bridges and barriers to developing and conducting interdisciplinary graduate-student team research. Ecology and Society 12(2):8. [online] URL: http://www.ecologyandsociety. org/vol12/iss2/art8/

Moser, S. C., and L. Dilling. 2011. Communicating climate change: closing the science-action gap. Pages 161-176 in J. S. Dryzek, R. B. Norgaard, and D. Schlosberg, editors. The Oxford handbook of climate change and society. Oxford University Press, Oxford, UK. http://dx.doi.org/10.1093/0xfordhb/9780199566600.003.0011

Mucina, L., and M. C. Rutherford. 2006. The vegetation of South Africa, Lesotho and Swaziland. Strelitzia 19. South African National Biodiversity Institute, Pretoria, South Africa.

O'Brien, K. 2013. Global environmental change III: closing the gap between knowledge and action. Progress in Human Geography 37(4):587-596. http://dx.doi.org/10.1177/0309132512469589

O'Farrell, P. J., and P. M. L. Anderson. 2010. Sustainable multifunctional landscapes: a review to implementation. Current Opinion in Environmental Sustainability 2(1-2):59-65. http://dx. doi.org/10.1016/j.cosust.2010.02.005

Pfeffer, J., and R. I. Sutton. 2000. The knowing-doing gap: how smart companies turn knowledge into action. Harvard Business School Press, Boston, Massachusetts, USA.

Pohl, C. 2008. From science to policy through transdisciplinary research. Environmental Science and Policy 11(1):46-53. http://dx. doi.org/10.1016/j.envsci.2007.06.001

Pooley, S. P., J. A. Mendelsohn, and E. J. Milner-Gulland. 2014. Hunting down the chimera of multiple disciplinarity in conservation science. Conservation Biology 28(1):22-32. http://dx. doi.org/10.1111/cobi.12183

Pullin, A. S., T. M. Knight, D. A. Stone, and K. Charman. 2004. Do conservation managers use scientific evidence to support their decision-making? Biological Conservation 119(2):245-252. http:// dx.doi.org/10.1016/j.biocon.2003.11.007 
Reyers, B., D. J. Roux, R. M. Cowling, A. E. Ginsburg, J. L. Nel, and P. O. Farrell. 2010. Conservation planning as a transdisciplinary process. Conservation Biology 24(4):957-965. http://dx.doi.org/10.1111/j.1523-1739.2010.01497.x

Rice, M. 2013. Spanning disciplinary, sectoral and international boundaries: a sea change towards transdisciplinary global environmental change research? Current Opinion in Environmental Sustainability 5(3-4):409-419. http://dx.doi.org/10.1016/j. cosust.2013.06.007

Roberts, D., R. Boon, N. Diederichs, E. Douwes, N. Govender, A. Mcinnes, C. Mclean, S. O'Donoghue, and M. Spires. 2012. Exploring ecosystem-based adaptation in Durban, South Africa: "learning-by-doing" at the local government coal face. Environment and Urbanization 24(1):167-195. http://dx.doi. org/10.1177/0956247811431412

Roberts, D., and N. Diederichs. 2002. Durban's Local Agenda 21 programme: tackling sustainable development in a post-apartheid city. Environment and Urbanization 14(1):189-201. http://dx.doi. org/10.1177/095624780201400116

Roux, D. J., K. H. Rogers, H. C. Biggs, P. J. Ashton, and A. Sergeant. 2006. Bridging the science-management divide: moving from unidirectional knowledge transfer to knowledge interfacing and sharing. Ecology and Society 11(1):4. [online] URL: http:// www.ecologyandsociety.org/vol11/iss1/art4/

Roux, D. J., R. J. Stirzaker, C. M. Breen, E. C. Lefroy, and H. P. Cresswell. 2010. Framework for participative reflection on the accomplishment of transdisciplinary research programs. Environmental Science and Policy 13(8):733-741. http://dx.doi. org/10.1016/j.envsci.2010.08.002

Seto, K. C., B. Güneralp, and L. R. Hutyra. 2012. Global forecasts of urban expansion to 2030 and direct impacts on biodiversity and carbon pools. Proceedings of the National Academy of Sciences 109(40):16083-16088. http://dx.doi.org/10.1073/pnas.1211658109

Shackleton, C. M., G. Cundill, and A. T. Knight. 2009. Beyond just research: experiences from Southern Africa in developing social learning partnerships for resource conservation initiatives. Biotropica 41(5):563-570. http://dx.doi.org/10.1111/ j.1744-7429.2009.00559.x

Sitas, N., H. E. Prozesky, K. J. Esler, and B. Reyers. 2014. Exploring the gap between ecosystem service research and management in development planning. Sustainability 6 (6):3802-3824. http://dx.doi.org/10.3390/su6063802

Steenkamp, Y., B. Van Wyk, J. Victor, D. Hoare, G. Smith, T. Dold, and R. Cowling. 2004. Maputaland-Pondoland-Albany. Pages 219-228 in R. A. Mittermeier, P. Robles-Gil, M. Hoffman, J. Pilgrim, T. Brooks, C. G. Mittermeier, J. Lamoreux, G. A. B. Da Fonesca, editors. Hotspots revisited: Earth's biologically richest and most endangered ecoregions. Cemex, Mexico City, Mexico.

Stelzer, R. S., and D. R. Kashian. 2014. The role of conservation partnerships between scientists and nonprofit agencies in freshwater science and management. Freshwater Science 33 (2):670-673. http://dx.doi.org/10.1086/675770
Stewart, G. B., C. F. Coles, and A. S. Pullin. 2005. Applying evidence-based practice in conservation management: lessons from the first systematic review and dissemination projects. Biological Conservation 126(2):270-278. http://dx.doi.org/10.1016/ j.biocon.2005.06.003

Stokols, D., J. Fuqua, J. Gress, R. Harvey, K. Phillips, L. Baezconde-Garbanati, J. Unger, P. Palmer, M. A. Clark, S. M. Colby, G. Morgan, and W. Trochim. 2003. Evaluating transdisciplinary science. Nicotine and Tobacco Research 5 (Supplement 1):S21-S39. http://dx.doi.org/10.1080/1462220031$\underline{0001625555}$

Stokols, D., K. L. Hall, B. K. Taylor, and R. P. Moser. 2008. The science of team science: overview of the field and introduction to the supplement. American Journal of Preventative Medicine 35(2 Supplement):S77-S89. http://dx.doi.org/10.1016/j.amepre.2008.05.002

Swilling, M. 2014. Rethinking the science-policy interface in South Africa: experiments in knowledge co-production. South African Journal of Science 110(5\&6):1-7. http://dx.doi. org/10.1590/sajs.2014/20130265

Uhl-Bien, M., R. Marion, and B. McKelvey. 2007. Complexity leadership theory: shifting leadership from the industrial age to the knowledge era. Leadership Quarterly 18(4):298-318. http://dx. doi.org/10.1016/i.leaqua.2007.04.002

van Kerkhoff, L. 2014. Developing integrative research for sustainability science through a complexity principles-based approach. Sustainability Science 9(2):143-155. http://dx.doi. org/10.1007/s11625-013-0203-y

van Kerkhoff, L., and L. Lebel. 2006. Linking knowledge and action for sustainable development. Annual Review of Environment and Resources 31(1):445-477. http://dx.doi. org/10.1146/annurev.energy.31.102405.170850

Wale, E., N. Chishakwe, and R. Lewis-Lettington. 2009. Cultivating participatory policy processes for genetic resources policy: lessons from the genetic resources policy initiative (GRPI) project. Biodiversity and Conservation 18(1):1-18. http://dx.doi. org/10.1007/s10531-008-9444-y

Wals, A. E. J. 2011. Learning our way to sustainability. Journal of Education for Sustainable Development 5(2):177-186. http://dx. doi.org/10.1177/097340821100500208

Whitten, T., D. Holmes, and K. MacKinnon. 2001. Conservation biology: a displacement behavior for academia? Conservation Biology 15(1):1-3. http://dx.doi.org/10.1111/j.1523-1739.2001.01 01. $\underline{\mathrm{x}}$

Wilhelm-Rechmann, A., and R. M. Cowling. 2011. Framing biodiversity conservation for decision makers: insights from four South African municipalities. Conservation Letters 4(1):73-80. http://dx.doi.org/10.1111/j.1755-263x.2010.00149.x

Wyborn, C. A. 2015. Connecting knowledge with action through coproductive capacities: adaptive governance and connectivity conservation. Ecology and Society 20(1):11. http://dx.doi. org/10.5751/es-06510-200111 
Appendix 1: The local context: An endangered grassland ecosystem in Durban, KwaZulu-Natal, South Africa

\section{The KwaZulu-Natal Sandstone Sourveld Grassland Ecosystem}

The KwaZulu-Natal Sandstone Sourveld (KZNSS) grassland ecosystem is recognized as a distinct vegetation type in South Africa, which is endemic to KwaZulu-Natal (Mucina \& Rutherford 2006, Jewitt 2011). It is a short, species-rich grassland with scattered low shrubs (for example members of the family Proteaceae) and woody plants with underground rhizomes. The KZNSS landscape is dominated by plateau tops forming characteristic 'table mountains' formed from erosion-resistant Natal Group Sandstone (NGS). Soils are shallow, nutrient poor and sandy, and underlain with NGS. A number of endemic plant species occur within this vegetation type (for further details refer to Mucina \& Rutherford 2006). The primary drivers of loss in this ecosystem are agriculture (mostly sugarcane and timber plantations), the urban sprawl of the eThekwini Municipal Area and densely populated subsistence farming areas (Mucina \& Rutherford 2006). The KZNSS is listed as a threatened ecosystem and considered endangered nationally and critically endangered at a provincial and local level (Jewitt 2011). As at 2008 only $11.4 \%$ of this vegetation type remained as natural habitat and only 194 ha $(0.1 \%)$ is formally protected (Jewitt 2011). At a local level, only 116 ha i.e. $0.74 \%$, of the area of KZNSS is locally protected in the eThekwini Municipality, and the total remaining area of KZNSS in the eThekwini Municipal Area (3259 ha) is below the conservation target for this vegetation type (3920 ha), as determined by the Systematic Conservation Planning process (eThekwini Municipality 2012).

\section{Incorporating biodiversity management and climate change adaptation into local land-use planning in Durban}

Durban, an urban metropolitan area governed locally by eThekwini Municipality, covers an area of almost $2300 \mathrm{~km}^{2}$ and is home to approximately 3.5 million people (eThekwini Municipality 2012). The ongoing influx of unemployed migrants from rural areas, along with endogenous growth, movement out of the CBD and land tenure complexities continue to put pressure on certain city resources, notably land (eThekwini Municipality 2014). As a result, Durban's natural ecosystems, and the services they provide, are under considerable strain (eThekwini Municipality 2012, Roberts et al. 2012).

EThekwini Municipality is one of the few municipalities in South Africa to have included environmental issues in its Integrated Development Plan (Cilliers et al. 2014, eThekwini Municipality 2014). It is also recognized as a leader in the development of policy to support implementation of sustainability issues in local governance and spatial planning among developing countries (Cilliers et al. 2014). EThekwini Municipality has developed a Municipal Climate Protection Program, which emphasizes ecosystem-based adaptation and has raised the profile of natural ecosystems within the city, by demonstrating the important links between healthy ecosystems and human well-being (Roberts et al. 2012). The city also has in place a spatial planning layer called D'MOSS (Durban Metropolitan Open Space System), the basis of which is a fine-scale systematic conservation plan (SCP) (Roberts et al. 2012). D'MOSS is used as a city-wide spatial planning and management support tool, which seeks to inform decision makers, citizens and land managers about the city's globally significant biodiversity. It also helps to ensure that the ecosystem services provided by these open spaces are not lost to urban development (Roberts et al. 2012). The need for relevant and scientifically sound, evidence-based knowledge is particularly important in the context of environmental impact assessments which are required by law in South Africa (Cilliers et al. 2014). Listed critically endangered ecosystems trigger environmental impact assessments prior to development, and are thus afforded some legal protection (National Environmental Management: Biodiversity Act No. 10 of 2004 and National Environmental Management Act No. 107 of 1998). 


\section{LITERATURE CITED FOR APPENDIX 1}

Cilliers, S., M. du Toit, J. Cilliers, E. Drewes, and F. Retief. 2014. Sustainable urban landscapes: South African perspectives on transdisciplinary possibilities. Landscape and Urban Planning 125:260-270.

eThekwini Municipality 2012. State of Biodiversity Report: 2011/2012. Environmental Planning and Climate Protection Department, eThekwini Municipality, Durban. Available online: http://www.durban.gov.za/City_Services/development_planning_management/environmental_plannin g_climate_protection/Publications/Documents/State_of_Biodiversity_Report_2011_2012.pdf (accessed February 2014).

eThekwini Municipality 2014. eThekwini Municipality Integrated Development Plan: Annual Review 2013/2014. eThekwini Municipality, Durban. Available online: http://www.durban.gov.za/City_Government/City_Vision/IDP/Documents/eThekwini\%20IDP\%2020 13_14.pdf (accessed March 2014).

Jewitt, D. 2011. Conservation targets and status for vegetation types in KZN. Unpublished internal report. Biodiversity Conservation Planning Division, Ezemvelo KZN Wildlife, P.O. Box 13053, Cascades, Pietermaritzburg, 3202. Available online: http://www.bgis.sanbi.org/KZN/KZN_vegetationtypes_conservationtargetstatusreport.pdf (accessed March 2014).

Mucina, L., and M. C. Rutherford 2006. The vegetation of South Africa, Lesotho and Swaziland. Strelitzia 19. South African National Biodiversity Institute, Pretoria.

Roberts, D., R. Boon, N. Diederichs, E. Douwes, N. Govender, A. Mcinnes, C. Mclean, S. O'Donoghue, and M. Spires. 2012. Exploring ecosystem-based adaptation in Durban, South Africa: "learning-bydoing" at the local government coal face. Environment and Urbanization 24:167-195. 
Appendix 2: History and organizational arrangements of the partnership

\section{History of the partnership}

The research partnership between eThekwini Municipality (EM) and the University of KwaZulu-Natal (UKZN), now known as the Durban Research Action Partnership (D'RAP), dates back to 2004, though it was only formalized in 2011. The partnership was originally known as the EM-UKZN Joint Research Partnership, and was given the new name D'RAP in 2015. A historical timeline which explains the significant steps in the development of the partnership is provided in Table A2.1. Taking time to build relationships is a key lesson learnt in this partnership (Table A2.1), as is the formalization of agreements (Figure $1 b$ ). During the process leading up to formalization, an effort was made by both partners to balance the input from both scientists and practitioners and mutually respect each other's expertise, a further enabling factor identified in the partnership (Figure 1a). This process culminated in the now well-established research partnership which is currently implemented through the KwaZulu-Natal Sandstone Sourveld Research Program (KZNSS). It was formalized through a contractually binding Memorandum of Agreement (MOA), signed between EM and UKZN, which informs the first phase of the program (2011-2014) (Figure 1b). The KwaZulu-Natal Sandstone Sourveld (KZNSS) Research Program is the first research program implemented through D'RAP to explicitly address the scienceaction gap in Durban. This focused research program on a particularly threatened grassland ecosystem grew out of the need to ensure that the broader D'RAP partnership addressed specific research needs as determined by EM, rather than taking too broad an approach across the whole of the eThekwini Municipal Area.

The objectives of the KZNSS Research Program are to:

Increase understanding and knowledge of biodiversity, ecosystem functioning and land use changes,

Assist EM with decision-making for land use planning, management and conservation,

- $\quad$ Address specific climate change challenges,

- $\quad$ Develop monitoring protocols to assess the impacts of climate change, and

- $\quad$ Increase human capital in the above areas.

The partnership was initially core funded by eThekwini Municipality, but has since leveraged additional resources through university researchers having independently accessed external co-funding. As of October 2014, forty-nine people have participated in the programme, from a range of disciplines, and 20 students are currently working on, or have completed, Honors or Masters level studies (Supplementary Box 2). The following academic disciplines are represented: ecology (plant biogeography, plant ecophysiology, terrestrial vertebrate zoology, plant and animal diversity), molecular biology (invertebrate genetics), agricultural economics, geography (remote sensing and GIS), and conservation planning and management. Some disciplines, considered essential to the partnership, such as sociology, political science and development studies, are presently under-represented, but efforts are underway to broaden the representation of such disciplines. 
Table A2.1: Summary of significant events and milestones in the development of the Durban Research Action Partnership, indicating alignment with the developmental stages of the transdisciplinary process as illustrated in Figure 2

\begin{tabular}{|c|c|c|}
\hline Date & Event & Outcome and implications \\
\hline \multicolumn{3}{|c|}{ Stage 0: Prospecting - Lead-in stage } \\
\hline $\begin{array}{l}2003 \text { to } \\
2005\end{array}$ & $\begin{array}{l}\text { Outsourced Training Program } \\
\text { University graduates in environmental and } \\
\text { biodiversity science placed into a targeted training } \\
\text { program to improve their environmental } \\
\text { management skills. Training contracted by the } \\
\text { Environmental Planning and Climate Protection } \\
\text { Department (EPCPD - then known as the } \\
\text { Environmental Management Department) of } \\
\text { eThekwini Municipality (EM) to the Council for } \\
\text { Scientific and Industrial Research (CSIR). }\end{array}$ & $\begin{array}{l}\text { Unsuccessful. } \\
\text { The program was expensive, and only one } \\
\text { out of five candidates was suitable for } \\
\text { employment due to lack of specialist } \\
\text { biodiversity skills. Recognition of the need } \\
\text { for a different way to build capacity and need } \\
\text { to find a new knowledge partner. }\end{array}$ \\
\hline $\begin{array}{l}2006 \text { to } \\
2008\end{array}$ & $\begin{array}{l}1^{\text {st }} \text { EM-UKZN Internship Program } \\
\text { MSc students from the University of KwaZulu- } \\
\text { Natal (UKZN) co-supervised by staff from } \\
\text { EPCPD and academics from UKZN in research } \\
\text { projects to provide them with the specialist } \\
\text { biodiversity skills needed by the EPCPD. }\end{array}$ & $\begin{array}{l}\text { Successful, but resource-expensive. } \\
\text { Despite both candidates being suitable for } \\
\text { employment by the EPCPD, the time } \\
\text { investment required for co-supervision by } \\
\text { EPCPD staff was extensive and difficult to } \\
\text { sustain. Recognition by EPCPD that UKZN } \\
\text { seemed like the right knowledge and training } \\
\text { partner. }\end{array}$ \\
\hline $\begin{array}{l}\text { Early } \\
2008\end{array}$ & $\begin{array}{l}\text { Refresher course in biodiversity and conservation: } \\
\text { capacity training (UKZN to EPCPD on a } \\
\text { consulting basis) } \\
\text { UKZN researchers appointed to provide scientific, } \\
\text { short-term, training to ecologists at EPCPD to } \\
\text { update them on current ecological theory relevant } \\
\text { to their work. }\end{array}$ & $\begin{array}{l}\text { Successful. } \\
\text { Relationships were built not only between the } \\
\text { primary leaders but also between leaders and } \\
\text { other staff members of the two institutions. } \\
\text { Trust- and confidence-building for delivery } \\
\text { and relevance of academia for practice. }\end{array}$ \\
\hline 2008 & $\begin{array}{l}\text { Support from university researchers to develop } \\
\text { EPCPD's strategic plan (UKZN to EPCPD on a } \\
\text { consulting basis): UKZN researchers appointed to } \\
\text { provide scientific input into the EPCPD strategic } \\
\text { plan and ensure alignment with current } \\
\text { environmental research trends. }\end{array}$ & $\begin{array}{l}\text { Successful. } \\
\text { Relationships built during the ecological } \\
\text { training earlier in the year further developed } \\
\text { and trust built. Increasing ecological } \\
\text { knowledge and confidence of EPCPD } \\
\text { lowered power gradients. Further trust- and } \\
\text { confidence-building for delivery and } \\
\text { relevance of academia for practice. }\end{array}$ \\
\hline \multicolumn{3}{|c|}{ Stage A: Exploring } \\
\hline 2010 & $\begin{array}{l}\text { Negotiations towards a Memorandum of } \\
\text { Understanding (MOU) for the Durban Research } \\
\text { Action Partnership: Included formal institutional } \\
\text { and legal processes as well as content } \\
\text { development of the formal, binding contract used } \\
\text { to inform the work of the partnership. }\end{array}$ & $\begin{array}{l}\text { Successful. } \\
\text { Participants from both institutions were } \\
\text { involved in developing the MOU for the } \\
\text { Durban Research Action Partnership. This } \\
\text { further built relationships and trust. }\end{array}$ \\
\hline
\end{tabular}


2011 Support and insights from EPCPD practitioners (on an informal basis) for UKZN applications for large research funding grants (e.g. South African Research Chair Initiative and Centre of Excellence for Applied Centre for Climate and Earth Systems Science).

Successful.

The partnership provided a foundation for generating the applications. It had highlighted collective EM-UKZN capacity in the research area which the grants focused on and had aligned academic thinking with applied outcomes as required by the grants. The process developed an understanding in both teams for the benefits of the partnership for both parties.

Questionable outcome due to difficulty in finding a suitable biology candidate and the insufficient capacity for supervision. The risk posed by not identifying suitable candidates made it not worth the high resource investment, particularly when compared to the resource-efficient KZNSS Research Program.

\section{Stage B: Consolidating - started during this next period of the partnership}

2011 to Durban Research Action Partnership: Phase 1

2014 The first phase of the research program was initiated in 2011, and was formalised through the signing of a Memorandum of Agreement between UKZN and the EPCPD. The EPCPD would provide research funding, and researchers at UKZN would conduct scientific research based on research questions jointly developed by the EPCPD and UKZN to provide research input for biodiversity conservation and management in the face of global climate change. A more specific focus was then developed to address the conservation and management of the KwaZuluNatal Sandstone Sourveld (KZNSS) grassland ecosystem in eThekwini Municipality. The KZN SS Research Program became the first focused research program for the implementation of the broader partnership.

2015 New name for the partnership, along with a logo: The Durban Research Action Partnership (D'RAP).
Mostly successful, necessary improvements identified through evaluation and reflection. Building relationships and trust and laying a foundation for future collaboration was a key part of this stage, as was developing further leadership at different levels i.e. secondary leadership.

Baseline biodiversity, ecosystem functioning and land use change knowledge of the KZNSS generated, approximately 10 students have graduated with the relevant skills, and a successful collaborative research partnership i.e. a 'boundary organisation', has been established. However, research needs to become more focused on EM's needs in Phase 2, building on the foundations. The research partnership was deemed a better investment of time and financial resources than the internship.

Successful.

The new name of the partnership and logo symbolised consolidation of the group's shared identity and explicit recognition of bridging the research-action (or scienceaction) gap (Figure A2.1 B).

Stage C: Integrating

Re-start Stage A: Exploring for new disciplines and research themes

2014 to Durban Research Action Partnership: Phase 2

2017 Based on the successes of the first phase, it was proposed that the research partnership be extended by another 3-year funding phase to continue implementation of the KZN SS Research Program. Funding allocation by eThekwini Municipality runs in 3-year cycles, and approval for Phase 2 is pending.
To be determined.

A solid foundation has been built for the collaboration. Integration of data across disciplines and into practice need to be prioritised, along with addressing significant research gaps e.g. socio-economic and governance research, more focused climate change research. 


\section{Organizational arrangements of the KZNSS Research Program}

The Durban Research Action Partnership was officially started in May 2011 with the signing of a Memorandum of Agreement (MOA) between eThekwini Municipality, more specifically the Environmental Planning and Climate Protection Department (EPCPD) and the University of KwaZulu-Natal (UKZN), through the College of Agriculture, Engineering and Science. According to the MOA, the joint research partnership in the area of biodiversity conservation and management in the face of global change would have two components: Firstly, the EThekwini Municipality-University of KwaZulu-Natal MSc Research Internship would continue (see Table A1.1), and secondly, a joint interdisciplinary research partnership between the Municipality and the university would be initiated. Within a few months of the formal umbrella partnership starting, it was agreed that a more focused research area was needed. This resulted in the development of the KwaZulu-Natal Sandstone Sourveld Research Program, which became the first focused research program implemented through the partnership. The Municipality provided seed funding and research direction for the partnership, in line with the EPCPD's vision and mission, and the university provided research input in the form of supervised student projects. The specific research questions were to be jointly identified, and would be implemented through the KZNSS Research Program. By having students conduct the research under supervision (rather than researchers themselves doing the research), the additional goal of building local human capacity in biodiversity, environmental management and climate change adaptation would also be reached.

This MOA was valid for a period of 3 years (July 2011-June 2014), and is currently under review for an extension into Phase 2 of the program. Over the first three years of the program, approximately 50 people have been involved, with a larger proportion of university staff and students compared to Municipality staff (Table A4.1). The program was run through a steering committee, representing leadership from both the Municipality and the university. The steering committee met regularly to discuss progress on the research, and principal investigators (PIs) and students were invited to present progress on their research to the steering committee bi-annually to receive feedback and suggestions and to ensure alignment of research projects with the overall program goals. PIs were expected to submit written progress reports on their research bi-annually and these were assessed by the steering committee. Smaller working group meetings were scheduled on an ad-hoc basis to discuss specific aspects of the program, for example development of a research framework, data management and monitoring, evaluating the partnership, and publishing outputs. Site visits were also arranged for UKZN staff and students to get to know the KZNSS grasslands within eThekwini Municipality, and for Municipality staff to share their knowledge and insight around management and conservation of the key KZNSS sites (Figure A2.1 A). These site visits were also an important opportunity for participants from the university and the Municipality to get to know each other in a slightly less formal setting.

Table A2.2: Participants in the KZNSS Research Program:

\begin{tabular}{ll}
\hline Participants and institutions & How many? \\
\hline \hline EThekwini Municipality: Managers and/or scientists & 6 \\
University of KwaZulu-Natal: Researchers & 17 \\
University of KwaZulu-Natal: Students (MSc) & 10 \\
University of KwaZulu-Natal: Students (Honors) & 9 \\
University of KwaZulu-Natal: Externally funded students doing KZNSS-related research & 6 \\
University of KwaZulu-Natal: Administrative Assistant & 1 \\
Total number of participants & 49 \\
\hline
\end{tabular}
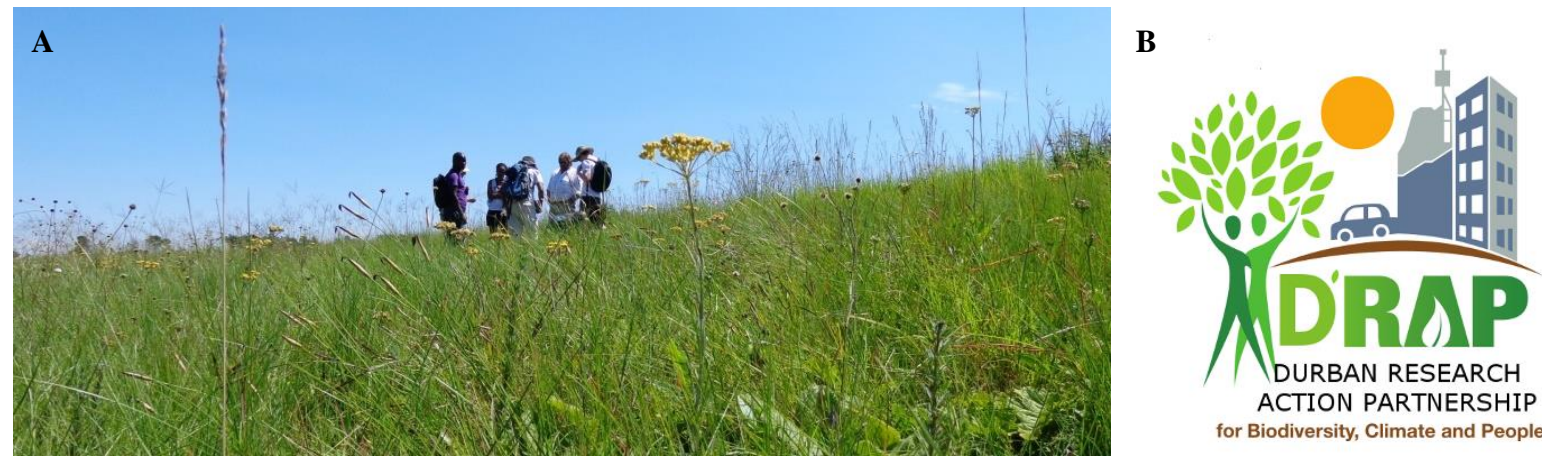

Figure A2.1: A: Site visit to KZNSS grasslands near Cato Ridge, on the western edge of the eThekwini Municipal Area. B: Logo of the Durban Research Action Partnership (D'RAP). 
Appendix 3: Case study methods and data

\section{Method}

An instrumental case study approach was used for this study, as the case is used to provide insight into a particular societal issue and to support theoretical propositions about the particular issue, i.e. briding the science-action gap through a transdisciplinary approach (Stake, 2005). The advantages of a case study research approach lies in its recognition of lessons from the particular rather than the general (Stake, 2005), and in the use of multiple sources of evidence (Yin, 2009). This is coupled with in-depth understanding of the case studies by researchers who are personally involved with the activities of the case and who are constantly reflecting on the meaning of what is going on in the case based on the theoretical propositions which guide the study (Stake, 2005).

This case study analysis was based on a three-step approach.

1. Gather data from various sources (see below)

2. Develop theoretical propositions (based on literature on the science-action gap, transdisciplinarity and collaboration, see Introduction and literature cited in Boxes 1-3)

3. Assess and describe the case study based on theoretical propostions to extract specific lessons from practice (see Fig. 1, and Table ).

An on-going iterative process was used to analyse the data, which allowed for reflection on the meaning generated by the data with respect to the theoretical propositions of the study (Stake, 2005).

\section{Data sources}

- Project documentation: minutes of meetings and workshops, quarterly progress reports, annual summary reports, final close-out report

- Evaluation documents and data: online survey questionnaires, reflection cards collected during meetings and workshops, records of outcome evaluations conducted during meetings and workshops.

- Semi-structured interviews with primary leaders who started the partnership about the history and organizational arrangements of the partnership (See Appendix 2).

- Focus group discussions with the core team during reflection sessions focused on the process evaluation of the partnership

\section{Curation of empirical data}

- Project documentation described above is all housed at both institutions: University of KwaZulu-Natal: Land Use Planning and Management Research Group (Pietermaritzburg Campus, KwaZulu-Natal, South Africa), eThekwini Muncipality: Environmental Planning and Climate Protection Department (City Engineers Building, Durban, KwaZulu-Natal, South Africa).

- Summaries of the most relevant project documentation is provided in Appendices attached to this manuscript (Appendix 1: The local context: An endangered grassland ecosystem in Durban, KwaZulu-Natal, South Africa, Appendix 2: History and organizational arrangements of the partnership, Appendix 4: Conceptual research framework and decision-making products of the KZNSS Research Program)

- The KwaZulu-Natal Sandstone Sourveld Research Programme Close-out Report is the most comprehensive source of information on the partnership, and includes records of all meetings and workshops. It is available online:

http://www.durban.gov.za/City_Services/development_planning_management/environmental_pla nning_climate_protection/Publications/Documents/KZNSS_Close_out_Report2011_2014.pdf

\section{LITERATURE CITED FOR APPENDIX 3:}


Stake, R. E., 2005. Qualitative Case Studies, In: Denzin, N.K., Lincoln, Y.S. (Eds.), The SAGE Handbook of Qualitative Research. Sage Publications, Inc, Thousand Oaks, California, pp. 443-466.

Yin, R. K., 2009. Case Study Research: Design and Methods. Sage Publications, Inc, Thousand Oaks, California. 
Appendix 4: Conceptual research framework and decision-making products of the KZNSS Research Program

For the purpose of clarity, the research framework is divided into two components: the research themes (Figure A4.1a), and the associated decision-making products (Figure A4.1b). The four major research themes (socio-economic context, land use change, biodiversity, and ecosystem function (Figure A4.1a) are aligned with decision-making products (Figure A4.1b). The decision-making products (numbered grey blocks) inform the research within each theme, and knowledge generated within each theme contributes to improved decision-making. Each of these decision-making products links to practical implementation activities of the Municipality (see Table A4.1 below).

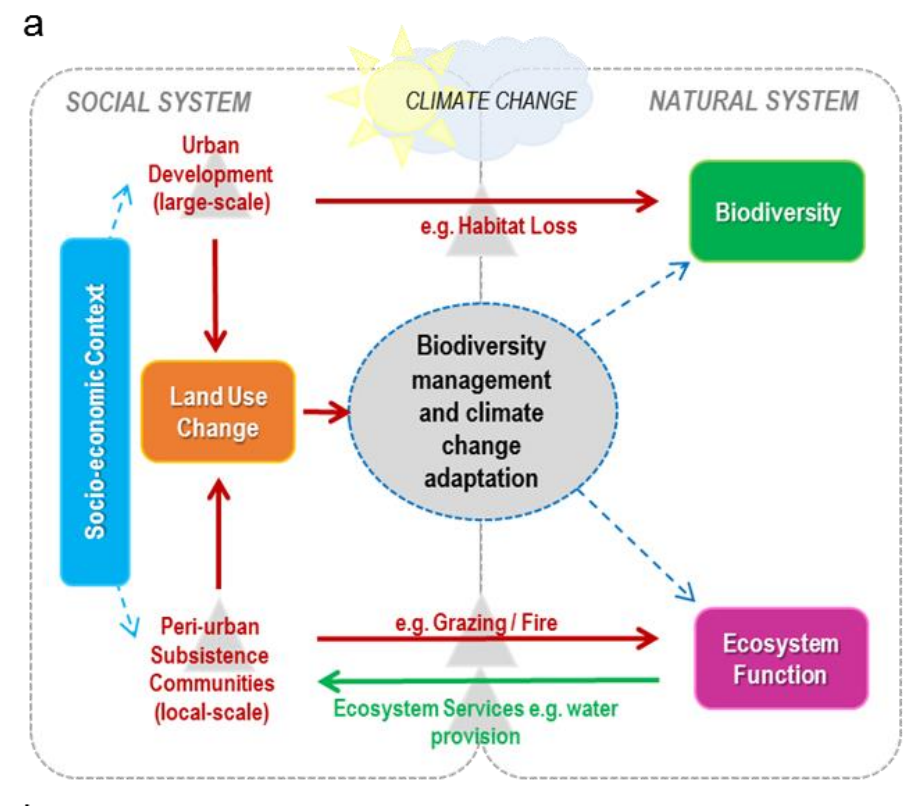

b

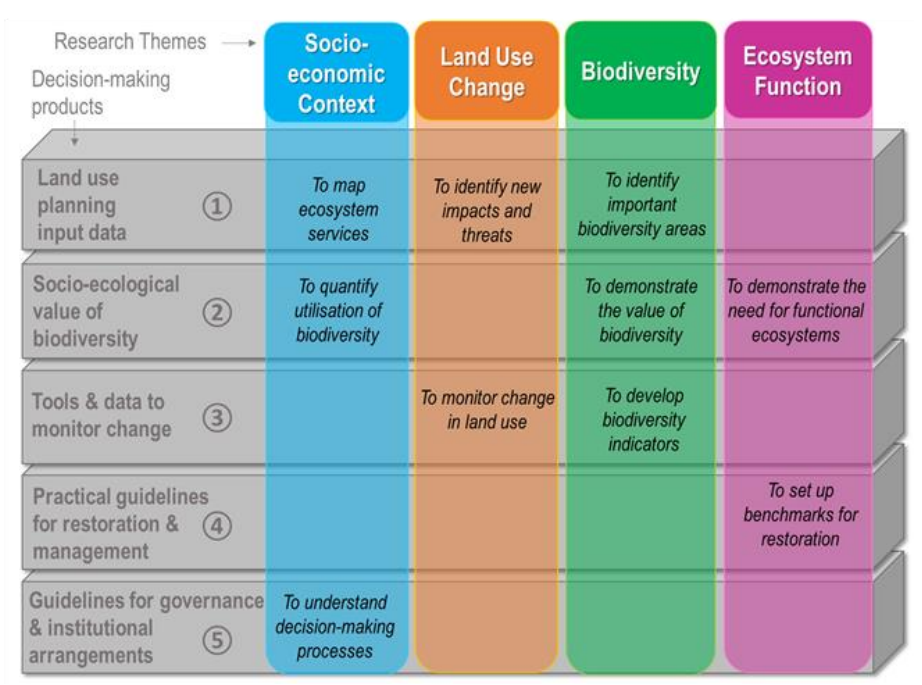

Figure A4.1: Conceptual research framework. Part a: the relationships between the four main research themes (socio-economic context, land use change, biodiversity and ecosystem function), and the various human drivers of ecosystem change (triangles and arrows) are illustrated. The central bubble represents the practice of biodiversity management and climate change adaptation at the Municipality. Part b: Alignment of research themes with decision-making products. The envisaged decision-making products are illustrated as grey boxes which knowledge generated by the four research themes contributes to, as illustrated by specific examples in black text. 
Table A4.1: Description of key decision-making products in the KZNSS conceptual research framework (Figure A4.1) demonstrating how they relate to practice of biodiversity management and climate change adaptation through various implementation activities at eThekwini Municipality (EM).

\begin{tabular}{|c|c|}
\hline $\begin{array}{l}\text { Decision-making } \\
\text { product }\end{array}$ & Relevance to practice and implementation activities at EM \\
\hline $\begin{array}{l}\text { 1. Land use planning } \\
\text { input data: }\end{array}$ & $\begin{array}{l}\text { These are data required for the Systematic Conservation Plan (SCP) and D'MOSS (Durban } \\
\text { Metropolitan Open Space System), which the Municipality has adopted as a tool for } \\
\text { identifying priority biodiversity and ecosystem services areas (Roberts et al., 2012). The } \\
\text { data required for the SCP include for example types and extent of spatial vegetation units } \\
\text { and species distribution data. }\end{array}$ \\
\hline $\begin{array}{l}\text { 2. Socio-ecological } \\
\text { value of biodiversity }\end{array}$ & $\begin{array}{l}\text { In its vision, the Environmental Planning and Climate Protection Department (EPCPD) } \\
\text { states that its purpose is to "speak out and take action on behalf of Biodiversity and } \\
\text { Climate Protection in Durban" (eThekwini Municipality, 2013). To this end, the } \\
\text { Municipality requires information on the social and ecological value of the biodiversity in } \\
\text { the city. Through its Biodiversity Impact Assessment Branch, the EPCPD screens } \\
\text { developments proposed for ecologically sensitive areas and makes recommendations about } \\
\text { where development should be avoided to protect biodiversity. These decisions should be } \\
\text { defendable in a court of law, and thus scientifically-robust information on the benefits of } \\
\text { protecting biodiversity is crucial. }\end{array}$ \\
\hline $\begin{array}{l}\text { 3. Tools and data to } \\
\text { monitor change: }\end{array}$ & $\begin{array}{l}\text { In order to "plan for, and implement measures to address climate change and its impacts" } \\
\text { (eThekwini Municipality, 2013) and to implement community and ecosystem-based } \\
\text { adaptation to climate change (Roberts et al., 2012), the Municipality requires baseline data } \\
\text { (environmental and biodiversity indicators of climate change) and a climate change } \\
\text { monitoring protocol, developed through a scientific process. }\end{array}$ \\
\hline $\begin{array}{l}\text { 4. Practical guidelines } \\
\text { for restoration and } \\
\text { management }\end{array}$ & $\begin{array}{l}\text { As part of its mandate "to conserve and enhance biodiversity and the beneficial } \\
\text { ecosystems" (eThekwini Municipality, 2013), the Municipality implements environmental } \\
\text { management on D'MOSS sites in several ways. These management functions require } \\
\text { technical input in order to optimise their practices, for example, best practice guidelines for } \\
\text { management of various ecosystem types and restoration strategies. }\end{array}$ \\
\hline $\begin{array}{l}\text { 5. Guidelines for } \\
\text { governance and } \\
\text { institutional } \\
\text { arrangements }\end{array}$ & $\begin{array}{l}\text { Land ownership and authority of the area under D'MOSS is diverse. EThekwini } \\
\text { Municipality has jurisdiction over some of the land, whilst some is privately owned, and } \\
\text { some is communally owned and administered by the Ingonyama Trust Board (ITB) on } \\
\text { behalf of the tribal authorities. Thus there is a need for collaborative governance } \\
\text { agreements and for the EPCPD to engage with private landowners and the ITB on issues of } \\
\text { biodiversity conservation, planning and management }\end{array}$ \\
\hline
\end{tabular}

\section{LITERATURE CITED FOR APPENDIX 4:}

eThekwini Municipality, 2013. EPCPD Strategy 2013-18: Background Report. Environmental Planning and Climate Protection Department, eThekwini Municipality, Durban.

Roberts, D., R. Boon, N. Diederichs, E. Douwes, N. Govender, A. Mcinnes, C. Mclean, S. O’Donoghue, and M. Spires, 2012. Exploring ecosystem-based adaptation in Durban, South Africa: "learning-by-doing" at the local government coal face. Environment and Urbanization 24(1), 167-195. 